\title{
Utilization of proteins for growth and egg production
}

\author{
By H. ERBersdobler, J. Gropp and H. BeCK, Institut für Tierphysiologie der \\ Universität München, 22 Veterinärstr. 13, 8 München West Germany
}

The amino acid requirements of poultry and the utilization of proteins in poultry nutrition have been studied intensively in the last 20 years. In the process this species, and above all growing chickens, have become the most thoroughly tested animals with regard to their nutritional requirements. On the other hand, the introduction of new protein sources like the single-cell proteins has created a lot of new problems which have not been solved as yet, although the amino acid patterns and the digestibility of the proteins seem to be fairly good.

\section{Methods of measuring protein utilization and recent experimental results}

Since experiments with higher animals are expensive and time-consuming, fastgrowing birds which at the same time have a high reproductive rate have become very popular. In recent years Japanese quail have frequently been used. The most important procedures are experiments measuring growth or egg production, and balance techniques.

As the protein needs of birds are comparatively high, greater amounts of supplementary protein sources are necessary. Above all, in the nutrition of the growing chicken the amount of protein contributed by cereals is relatively low. Therefore lysine, the limiting amino acid in cereals, does not play as important a part as methionine, which is limiting in the oil-seed proteins (see e.g. Erbersdobler \& Gropp, 1971). In rations for laying hens lysine may become marginal, mainly if the protein content of the diet is reduced to a low level and if greater amounts of proteins poor in lysine are used. In this connexion the use of newly developed lysine-rich cereals can be very helpful, as can be seen from two experiments with 'opaque-2' maize shown in Fig. I (Zucker, Erbersdobler \& Gropp, 1968; Chi \& Speers, 1973). In practical rations for broiler chickens these new cereal varieties cannot be recommended (see also Erbersdobler \& Gropp, 1971). They can, however, be very useful if protein sources poor in lysine or tryptophan are introduced more liberally.

Following the introduction of mixtures of crystalline amino acids, the requirements of poultry have been studied exactly, and reference amino acid mixtures have been defined for many purposes. We use a mixture with higher amounts of essential amino acids than is used in Illinois (see e.g. Huston \& Scott, 1968; Sasse \& Baker, 1973), but similar to the mixture of Lee \& Blair (1974). With this diet, containing in addition to sucrose as the sole carbohydrate source $150 \mathrm{~g}$ soya-bean oil $/ \mathrm{kg}$ and $10 \mathrm{~g}$ sodium hydrogen carbonate/kg in the mineral mixture, high growth rates for a long period 
(a)

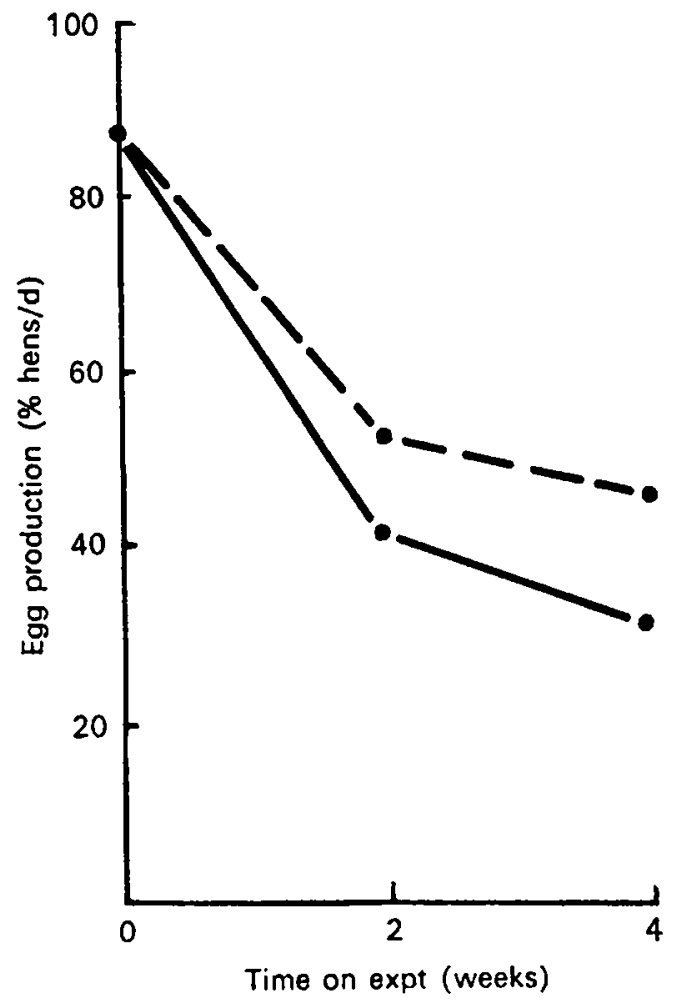

(b)

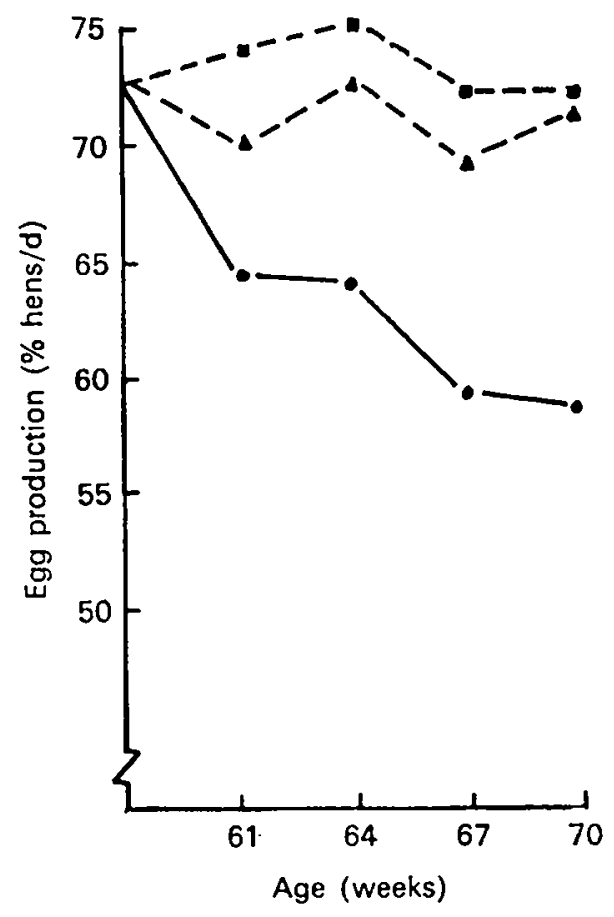

Fig. 1. Egg production (\% hens/d) of quail hens (a) and fowl hens (b) fed on low-protein diets (115-120 $\mathrm{g}$ protein $/ \mathrm{kg}$ ) containing mainly normal maize ( $\mathrm{N}$-maize) or opaque-2 maize (HL-maize) plus soya-bean meal (Zucker, Erbersdobler \& Gropp, 1968; Chi \& Speers, r973): (a) $\longrightarrow$ - N-maize $(33 \mathrm{~g}$ lysine/kg protein); $-\ldots$, HL-maize $(46 \mathrm{~g}$ lysine $/ \mathrm{kg}$ protein; (b) $\longrightarrow$, N-maize (30 g lysine/kg protein); - - $\square$, HL-maize (43 g lysine/kg); $\Delta---\Delta$, HL-maize (49 g lysine/kg protein).

can be obtained. With modern breeds of fast-growing broiler chickens (e.g. Lohmann B 975) weight gains of $14.8 \mathrm{~g} / \mathrm{d}$ from the ist to the $14^{\text {th }}$ day of life and of $20.6 \mathrm{~g} / \mathrm{d}$ from the ist to the 28 th day of life were found. These growth rates were higher than those of control groups fed with isolated soya-bean protein supplemented with methionine. The corresponding food conversion values were $1 \cdot 24$ (Ist-1 4 th day) and $\mathrm{r} \cdot 45 \mathrm{~g}$ food (Ist-28th day of life) /g weight gain (Gropp \& König, 1973; König, Erbersdobler \& Gropp, 1973).

With similar diets glycine has been found partially indispensable, although at the moment not all details of this problem are solved (Greene, Scott \& Johnson, I960; Hewitt \& Lewis, 1972a; Graber \& Baker, 1973). Several authors have also classified proline and glutamic acid as semi-essential amino acids (Graber, Allen \& Scott, 1970; Graber \& Baker, 1973; Maruyama, Harper \& Sunde, 1973). It seems to be unrealistic that these two amino acids could become limiting in practical diets; an adequate supply should, however, be taken into consideration if highly purified rations are given or if uncommon protein sources are used. The arginine requirements of birds 
are highly variable and depend on the lysine level in the diets. An excess of lysine stimulates the activity of kidney arginases, thus raising the requirement of arginine for protein synthesis (Austic \& Nesheim, 1970; Hewitt \& Lewis, 1972b). These problems are also of practical importance, since arginine is marginal in most of the single-cell proteins, which are moreover abundant in lysine. Many details of these mechanisms are still uncertain (Wang, Crosby \& Nesheim, 1973).

Another possibility is to add an amino acid mixture to a certain protein in a diet and then to subsequently remove, one by one, the essential amino acids from the mixture. Thus the growth rate is usually most decreased by the removal of the most deficient amino acid in the examined protein. This technique has been widely used for the determination of the limiting amino acids in several protein sources. Table $\mathrm{I}$ shows an example of experiments with quail chickens, determining the limiting amino acids in protein from yeasts grown on hydrocarbons (Beck, 1974; Gropp, Beck \& Erbersdobler, I975a).

Table 1. Determination of the limiting amino acid in yeasts grown on $\mathrm{n}$-paraffins: growth of quail chickens fed with rations" containing $190 \mathrm{~g}$ protein/kg from BP yeasts $\dagger$ and $38 \mathrm{~g}$ amino acid mixture $+/ \mathrm{kg}$

(Mean values for nineteen to twenty-four birds; the experiment lasted 3 weeks)

\begin{tabular}{|c|c|c|c|c|}
\hline & \multicolumn{2}{|c|}{ Body-weight gain } & \multicolumn{2}{|c|}{ Food conversion ratio } \\
\hline & (g) & $\begin{array}{l}\text { (\% gain with } \\
\quad \text { P }+ \text { AA) }\end{array}$ & $\begin{array}{l}\text { (g food intake/ } \\
g \text { wt gain }\end{array}$ & $\begin{array}{l}(\% \text { ratio } \\
\text { with } \mathbf{P}+\mathbf{A A})\end{array}$ \\
\hline $\begin{array}{l}\text { Yeast protein } \\
\text { Yeast protein }+ \text { amino }\end{array}$ & 31 & $66^{a}$ & $4 \cdot 3$ & $143^{e}$ \\
\hline acid mixture (P+AA) & 47 & $100^{b}$ & $3 \cdot 0$ & $100^{f}$ \\
\hline P+AA minus Met & $\ddot{-}$ & $50^{c}$ & - & $15^{\mathrm{e}}$ \\
\hline P- $\mathbf{A A}$ minus Arg & - & $82^{d}$ & 一 & $129^{8}$ \\
\hline & - & $109^{b}$ & 一 & $100^{f}$ \\
\hline Thr, Leu, Ileu or Phe & 一 & $101-106^{b}$ & - & $91-104^{f}$ \\
\hline \multicolumn{5}{|c|}{$\begin{array}{l}\text { Met, methionine; Arg, arginine; Gly, glycine; Lys, lysine; Try, tryptophan; Thr, } \\
\text { threonine; Leu, leucine; Ileu, isoleucine; Phe, phenylalanine. }\end{array}$} \\
\hline \multicolumn{5}{|c|}{$\begin{array}{l}\text { The basal ration contained }(\mathrm{g} / \mathrm{kg}): 300 \text { yeasts (a mixture from two types), } 520 \text { maize } \\
\text { starch, } 60 \text { oil, } 20 \text { cellulose; there were adequate minerals, trace elements and vitamins, } \\
\text { and supplementary methionine and arginine. } \\
\text { †British Petroleum Co. Ltd, London EC2. } \\
\text { IThis consisted of }(\mathrm{g}): \text { Lys } 3 \cdot 2 \text {, Arg } 8 \cdot 1 \text {, histidine } 1 \cdot 1 \text {, tyrosine } 2 \cdot 0, \text { Try } 0 \cdot 8 \text {, Phe } 2 \cdot 4 \text {, } \\
\text { Met } 4 \cdot 1, \text { cystine } 1 \cdot 2 \text {, Thr } 2 \cdot 2, \text { Leu } 4 \cdot 0 \text {, Ileu } 2 \cdot 4 \text {, valine } 2 \cdot 4 \text {, and glycine } 4 \cdot 6 \text {. } \\
\text { a,b,c,d,e,f,g Values in the same column having different superscripts are significantly }\end{array}$} \\
\hline
\end{tabular}

For several years many authors have recommended the use of balance techniques to measure protein utilization. In Rostock the early technique of Kuiken \& Lyman (1948), of balancing the amino acids instead of nitrogen, was adapted to the bird. Thus the separation of urine from the excreta could be avoided (e.g. Kristen, Poppe \& Wiesemüller, I966; Poppe \& Meier, I97 I).

But it has to be realized that the microflora of the large intestine may destroy or change some undigested amino acids or even synthesize new proteins (Miller, 1967; 
Salter \& Coates, 1969; Zebrowska, 1973). Thus misleading results may be obtained (Erbersdobler, 1967; Salter \& Coates, 1971). In order to prevent such changes of the nitrogenous compounds in the hind-gut, several variations of the digestibility trials were applied more or less successfully (e.g. Nesheim \& Carpenter, 1967; Soares \& Kifer, I97I ; Varnish \& Carpenter, 197I). We decided to carry out experiments with germ-free and conventionally housed chicks to measure the amino acids digestibility in a protein of high quality and in a heat-damaged sample (Erbersdobler, 1971; Erbersdobler \& Riedel, 1972). Similar experiments were carried out by Miller (1967), Salter \& Coates (1969, 1971), Salter, Coates \& Hewitt (1974), and Soares, Miller, Fitz \& Sanders (197I). Results of our last experiment are partially shown in Table 2.

Table 2. Apparent digestibility of amino acids in germ-free $(G F)$ and conventionally housed (CV) 3-week-old chicks. The diets contained $390 \mathrm{~g}$ protein $/ \mathrm{kg}$

(Mean values with their standard errors or ranges)

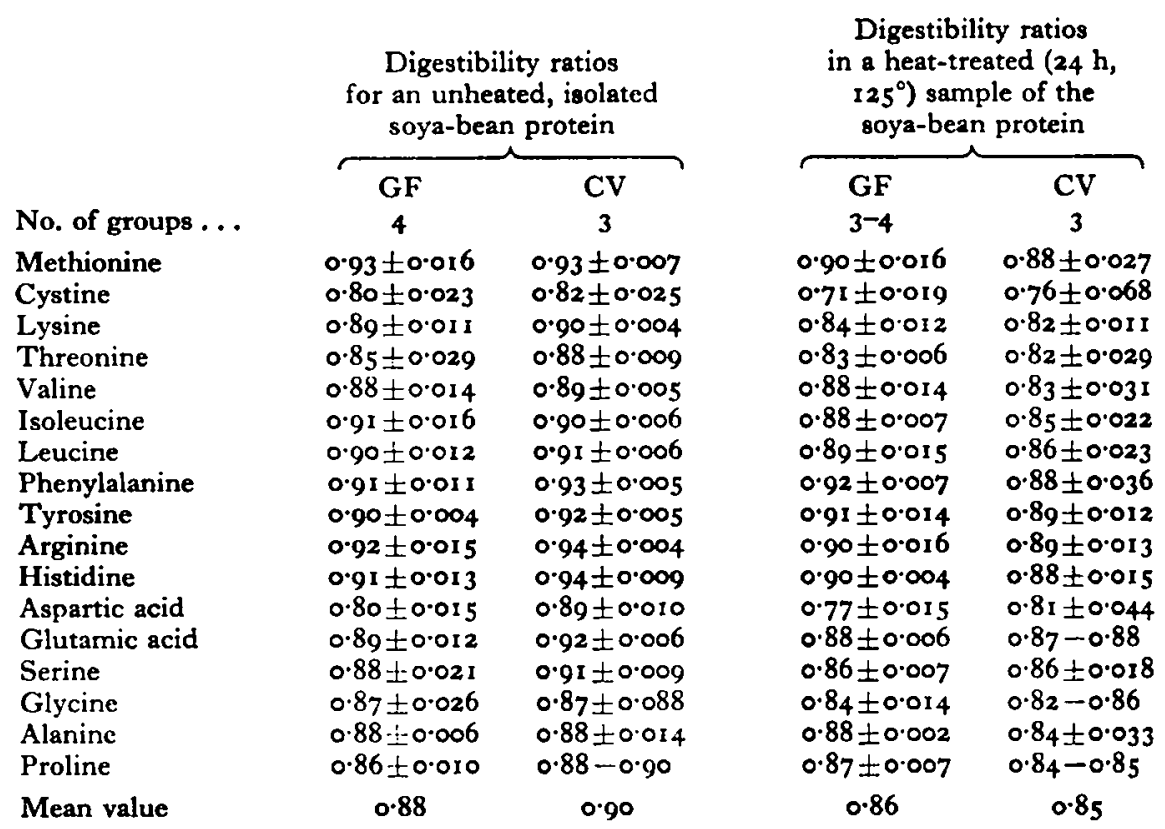

In all our experiments it was impossible to demonstrate greater losses of undigested amino acids caused by activity of micro-organisms. The results of Salter et al. (1974), who measured the utilization of protein in germ-free and conventionally housed chicks, are in good agreement with these findings. We assume that the activity of the micro-organisms in the hind-gut of birds is of importance only if low-protein or $\mathrm{N}$-free diets are given (see also Miller, 1967).

Another problem arises from the hydrolysis of the droppings, which also contain urine. We have seen that glycine is produced from uric acid during the hydrolysis (Erbersdobler \& Riedel, 1972, 1973). This is confirmed by the findings of Soares $e t$ al. (1971) and Gruhn (1973). We have seen that during hydrolysis with hydrochloric acid, glycine can be produced from purine and many purine derivatives. Undoubtedly 
this fact is of considerable physiological and analytical importance. Preliminary results of experiments with ${ }^{14} \mathrm{C}$-labelled purines suggest that the carbon atoms 5 and 6 , together with the $\mathrm{N}$ in position 7 in the purine nucleus, are involved in the formation of glycine. Cavalieri, Tinker \& Brown (1947) found that glycine arises from the 4,5 and 7 atoms of purine, in partial contradiction to our findings.

\section{Use and utilization of new protein sources}

The recent world-wide shortage of protein sources has shown that it is desirable to look for new protein sources as well as to try to utilize the by-products of human consumption to a greater extent. We have discussed these problems in detail in earlier papers (Erbersdobler, 1973a,b). In all instances birds proved to be not only suitable test animals but also important potential consumers, since most of these protein sources are not directly utilizable for human consumption.

One of the most revolutionary nutritional findings of the last 10 years has been the development of a method to produce single-cell proteins from unconventional energy sources. Carefully produced yeasts grown on hydrocarbons can be a good source of protein, as can be seen from many experiments (e.g. Shaklady, r969; Shannon \& McNab, 1972). It proved to be possible to use these types of yeasts, supplemented with DL-methionine, at up to $200 \mathrm{~g} / \mathrm{kg}$ in practical broiler diets (Gropp, Schulz \& Beck, 1972). With higher concentrations, a considerable depression in the performance of broiler chickens could be seen (Woodham \& Deans, 197 I Gropp et al. 1972; Erbersdobler, 1973a; Gropp, Beck \& Erbersdobler 1975b). For this reason we have not been able until now to develop a highly purified diet in which the yeast protein represents the only source of protein and which is as good as c.g. isolated soya-bean protein. However, this problem could almost be solved with quail chickens if the yeast protein was optimally supplemented with methionine and arginine (Gropp et al. 1975b). The mechanism responsible for the growth depression which occurred if greater amounts of the yeasts were fed to broiler chickens has not been clearly understood as yet, since the amino acid pattern and the digestibility of the protein seem to be very good. It may be connected with the non-protein fraction, e.g. the nucleic acids or some carbohydrates.

Similar problems arose in the course of our experiments with fresh sweet-water green algae (Scenedesmus obliquus, 276-3a; kindly given by Abteilung für Algenforschung und Algentechnologie der Gesellschaft für Strahlen- und Umweltforschung, Dortmund, West Germany (see Soeder \& Pabst, 1970)). In experiments with quail chickens, up to $25-30 \%$ of the total protein content of the diet could be replaced by the algal protein without disadvantage. The results of one of two experiments are given in Table 3 . In an experiment with three groups of laying hens, 0,30 and $60 \%$ of the total protein were substituted by the algal protein in rations with a protein content of $13 \circ \mathrm{g} / \mathrm{kg}$, which can be regarded as suboptimal almost in the first week.

The results of this trial are shown in Table 4. Obviously the amount of algal protein was too high considering the low level of protein in the diet. The egg yolk colour, however, was greatly improved. Further experiments should be made to find 
Table 3. Performance of quail chickens from $\mathrm{I}$ to $14 \mathrm{~d}$ old fed on diets* with various quantities of fresh sweet-water green algae (Scenedesmus obliquus 276-3a) $\dagger(G A)$

(Each treatment was of four groups, each containing ten birds)

\begin{tabular}{|c|c|c|c|c|c|}
\hline \multirow{2}{*}{$\begin{array}{l}\text { Protein } \\
\text { content } \\
\text { of diet } \\
(\mathbf{g} / \mathbf{k g})\end{array}$} & \multirow{2}{*}{$\begin{array}{c}\text { Protein } \\
\text { supplied } \\
\text { by GA } \\
(\mathbf{g} / \mathbf{k g})\end{array}$} & \multicolumn{2}{|c|}{ Final body-weight } & \multicolumn{2}{|c|}{ Food conversion ratio } \\
\hline & & (g) & $(\%$ control $)$ & $\begin{array}{l}\text { (g food intake/ } \\
\text { g wt gain) }\end{array}$ & ( $\%$ control) \\
\hline \multirow[t]{4}{*}{200} & ○ & 52 & $100^{a}$ & $2 \cdot 7$ & 100 \\
\hline & 50 & 52 & $100^{\alpha}$ & $2 \cdot 8$ & 104 \\
\hline & 100 & 49 & $94^{\mathrm{b}}$ & $2 \cdot 8$ & 104 \\
\hline & I 50 & $4 I$ & $79^{\mathrm{c}}$ & $3 \cdot 2$ & 119 \\
\hline \multirow[t]{4}{*}{300} & 0 & 66 & $100^{d}$ & $2 \cdot I$ & 100 \\
\hline & 50 & 66 & $100^{d}$ & $2 \cdot I$ & 100 \\
\hline & 100 & 65 & $98^{d}$ & $1 \cdot 9$ & 92 \\
\hline & 150 & 62 & $94^{e}$ & $2 \cdot 3$ & 108 \\
\hline
\end{tabular}

-The diets contained soya-bean meal, isolated soya-bean protein, oil, cellulose and maize starch. The calculated metabolizable energy content was $13.5 \mathrm{MJ} / \mathrm{kg}$. GA replaced isonitrogenously and isoenergetically a mixture of soya-bean meal and isolated soya protein. All diets were supplemented with methionine.

†Kindly given by Abteilung für Algenforschung und Algentechnologie der GSF, Dortmund, West Germany.

$a, b, c, d, e$ Values in the same column having different superscripts are significantly different.

Table 4. Performance of laying hens fed on diets* with various quantities of sweet-water green algae (Scenedesmus obliquus 276-3a) $†(G A)$

(Each group contained cleven or twelve singly-housed hens)

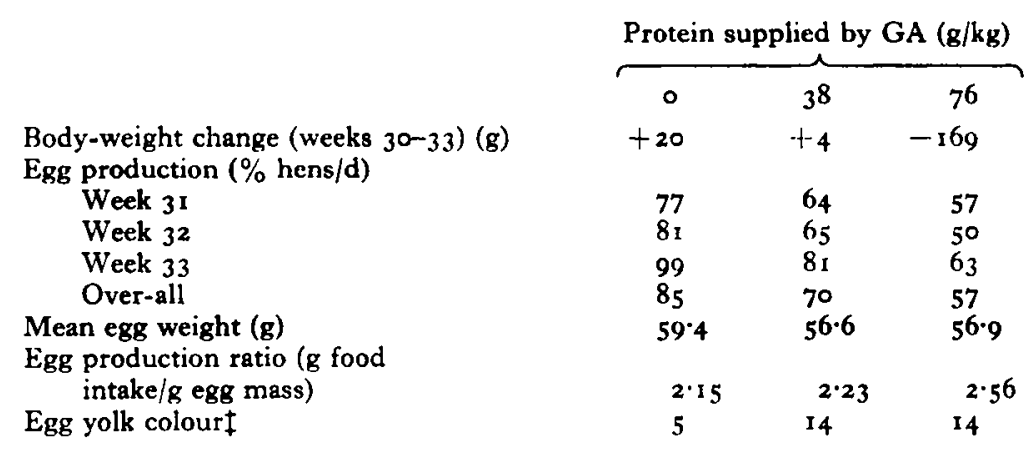

The diets contained maize meal, soya-bean meal, isolated soya-bean protein, and contained $50 \mathrm{~g}$ fat and $130 \mathrm{~g}$ protein $/ \mathrm{kg}$; the calculated metabolizable energy content was $13.5 \mathrm{MJ} / \mathrm{kg}$.

†Kindly given by Abteilung für Algenforschung und Algentechnologie der GSF, Dortmund, West Germany.

$\ddagger$ Graded by the 'Roche Yolk Colour Fan' (F. Hoffmann-La Roche \& Co. Ltd, Basel, Switzerland).

out the marginal amount of this algal protein in the nutrition of domestic fowl and especially of the laying hen.

'The third single-cell protein examined was bacterial biomass grown on methanol. In these experiments the poor performance of broiler chicks, which could be seen if amounts higher than $30 \mathrm{~g} / \mathrm{kg}$ were introduced into the diets, was improved if the 
Table 5. Performance of male broiler chicks fed on diets" with various quantities of bacterial biomass $\dagger(B B)$ grown on methanol

(Each treatment was on eight replicates with twelve birds.)

\begin{tabular}{|c|c|c|c|c|c|c|c|c|c|c|}
\hline \multirow{3}{*}{$\begin{array}{l}\text { Protein } \\
\text { content } \\
\text { of diet } \\
(\mathrm{g} / \mathrm{kg})\end{array}$} & \multirow{3}{*}{$\begin{array}{l}\text { Protein } \\
\text { supplied } \\
\text { by } \mathrm{BB} \\
(\mathrm{g} / \mathrm{kg})\end{array}$} & \multicolumn{3}{|c|}{ Body-weight at day 28} & \multicolumn{3}{|c|}{ Body-weight at day 45} & \multirow{2}{*}{\multicolumn{3}{|c|}{$\overbrace{\begin{array}{c}\mathrm{g} \text { food intake } \\
\mathrm{g} \text { wt gain }\end{array}}^{\text {Food conversion ratio }}$}} \\
\hline & & \multicolumn{2}{|c|}{$(\mathrm{g})$} & \multirow{2}{*}{$\begin{array}{c}(\% \\
\text { control) }\end{array}$} & \multicolumn{2}{|c|}{$(\mathrm{g})$} & \multirow{2}{*}{$\begin{array}{l}(\% \\
\text { control) }\end{array}$} & & & \\
\hline & & Mean & $\mathbf{S E}$ & & Mean & SE & & $\overparen{\text { Mean }}$ & $\mathbf{S E}$ & $\begin{array}{l}(\% \\
\text { control) }\end{array}$ \\
\hline 180 & $\begin{array}{r}0 \\
30\end{array}$ & $\begin{array}{l}659 \\
631\end{array}$ & $\begin{array}{l}30 \\
17\end{array}$ & $\begin{array}{r}100 \\
96\end{array}$ & $\begin{array}{l}1370 \\
1372\end{array}$ & $\begin{array}{l}73 \\
73\end{array}$ & $\begin{array}{l}100 \\
100\end{array}$ & $\begin{array}{l}2.0 \\
2 \cdot 0\end{array}$ & $\begin{array}{l}0.1 \\
0.1\end{array}$ & $\begin{array}{l}100 \\
100\end{array}$ \\
\hline $\begin{array}{c}180 \\
\text { (pelleted } \\
\text { diet) }\end{array}$ & $\begin{array}{l}60 \\
60\end{array}$ & $\begin{array}{l}570 \\
668\end{array}$ & $\begin{array}{l}19 \\
28\end{array}$ & $\begin{array}{r}87 \\
101\end{array}$ & $\begin{array}{l}1266 \\
1451\end{array}$ & $\begin{array}{l}69 \\
89\end{array}$ & $\begin{array}{r}92 \\
106\end{array}$ & $\begin{array}{l}2 \cdot 0 \\
1 \cdot 9\end{array}$ & $\begin{array}{l}0.1 \\
0.1\end{array}$ & $\begin{array}{r}106 \\
99\end{array}$ \\
\hline \multirow[t]{3}{*}{240} & $\circ$ & 757 & 35 & 100 & I 508 & 76 & 100 & $1 \cdot 9$ & 0.1 & 100 \\
\hline & $\begin{array}{l}90 \\
90\end{array}$ & 68 & 40 & $9 \mathrm{r}$ & 1425 & 78 & 95 & $1 \cdot 9$ & 0.1 & 102 \\
\hline & (pelleted $\downarrow$ ) & 748 & 29 & 99 & $153 \mathrm{I}$ & 25 & 102 & $1 \cdot 9$ & 0.1 & 98 \\
\hline
\end{tabular}

-The maize-soya-bean diets had a calculated metabolizable energy content of $\mathrm{I} 2 \cdot 78 \mathrm{MJ} / \mathrm{kg}$. BB replaced isonitrogenously and isoenergetically a mixture of isolated soya-bean protein, maize starch and cellulose. All diets were supplemented with methionine.

†From Pseudomonas strains, given by Imperial Chemical Industries Ltd, England.

fOnly the BB was pelleted.

rations or even the product alone were pelleted. The results of two trials with broiler chickens are given in Table 5. In our experiments about $40 \%$ of the total protein could be substituted by bacterial biomass if this product was pelleted. The growthdepressing effect of the unpelleted material, therefore, seemed to be connected with the fine and dusty structure of the product (D. A. Stringer, personal communication). These results are in good agreement with those of $\mathrm{H}$. Vogt (unpublished results) who used the same product and also did not find any depression in the performance of broiler chicks up to a level of $40 \%$ of the total protein in the diet. Higher levels than $60 \%$ had a significant growth-depressing effect (H. Vogt, personal communication).

\section{REFERENCES}

Austic, R. E. \& Nesheim, M. C. (1970). Y. Nutr. 100, 855 .

Beck, H. (1974). Studien über den Einsatz von Alkan-Hefen in der Geflügelernährung. Thesis, D. Vet. Sci., University of Munich.

Cavalieri, L. F., Tinker, J. F. \& Brown, G. B. (1947). J. Am. chem. Soc. 71, 3973.

Chi, M. S. \& Speers, G. M. (1973). Poult. Sci. 52, 1138.

Erbersdobler, H. (1967). Untersuchungen zur analytischen und physiologischen Charakterisierung der Aminosäurenschädigung bei Hitzbehandlung von Nahrungs- und Futtermitteln. Habilitationsschrift Thesis, University of Munich.

Erbersdobler, H. (1971). Z. Tierphysiol. Tierernähr. Futtermittelk. $27,217$.

Erbersdobler, H. (1973a). U.N. Publ. No. EFR 73 II.E, Mimeo. 8, vol. r, p. 144.

Erbersdobler, H. (1973b). Kraftfutter 56, 274.

Erbersdobler, H. \& Gropp, J. (1971). Arch. Geflügelk. 35, 36.

Erbersdobler, H. \& Riedel, G. (1972). Arch. Geflügelk. 36, 218.

Erbersdobler, H. \& Riedel, G. (1973). Proc, int. Amino Acid Symp., Brno A 29.

Graber, G., Allen, N. K. \& Scott, H. M. (1970). Poult. Sci. 49, 692.

Graber, G. \& Baker, D. H. (1973). Poult. Sci. 52, 892.

Greene, D. E., Scott, H. M. \& Johnson, B. C. (1960). Poult. Sci. 39, $5^{12}$. 
Gropp, J., Beck, H. \& Erbersdobler, H. (1975a) 2. Tierphysiol. Tierernähr. Futtermittelk. 34, I41. Gropp, J., Beck, H. \& Erbersdobler, H. (1975b). Z. Tierphysiol. Tierernähr. Futtermittelk. 34, 181 . Gropp, J. \& König, K. (1973). Naturwissenschaften 60, I6r.

Gropp, J., Schulz, V. \& Beck, H. (1972). Z. Tierphysiol. Tierernähr. Futtermittelk. 30, 155.

Gruhn, K. (1 973). Proc. int. Amino Acid Symp., Brno A 27.

Hewitt, D. \& Lewis, D. (1972a). Br. Poult. Sci. 13, 387.

Hewitt, D. \& Lewis, D. (1972b). Br. Poult. Sci. 13, 449.

Huston, R. L. \& Scott. H. M. (1968). Fedn Proc. Fedn Am. Socs exp. Biol. 27, 1204.

König, K., Erbersdobler, H. \& Gropp, J. (1973). Z. Tierphysiol. Tierernähr. Futtermittelk. $32,7$.

Kristen, H. S., Poppc, S. \& Wiesemüller, W. (1966). Arch. Gefiügelz. Kleintierk. 15, 317.

Kuiken, A. \& Lyman, C. M. (1948). J. Nutr. 36, 359.

Iee, D. J. W. \& Blair, R. (1974). Br. Poult. Sci. I5, 17.

Maruyama, K., Harper, A. E. \& Sunde, M. L. (1973). Poult. Sci. 52, 2060.

Miller, W. S. (1967). Proc. Nutr. Soc. 26, x.

Nesheim, M. C. \& Carpenter, K. J. (r967). Br. F. Nutr. 21, 399.

Poppe, S. \& Meicr, H. (1971). Arch. Tierernähr. $21,447$.

Salter, D. N. \& Coates, M. E. (1969). Proc. 8th int. Congr. Nutr., Prague p. 425.

Salter, D. N. \& Coates, M. E. (1971). Br. J. Nutr. 26, 55 .

Salter, D. N., Coates, M. E. \& Hewitt, D. (1974). Br. Y. Nutr. 31, 307.

Sasse, C. E. \& Baker, D. H. (1973). Poult. Sci. 52, 1970.

Shaklady, C. A. (1969). 8th int. Congr. Nutr., Prague.

Shannon, D. W. F. \& McNab, J. M. (1972). Br. Poult. Sci. 13, 267.

Soares, J. H. Jr \& Kifer, R. R. (1971). Poult. Sci. 50, 41 .

Soares, J. H. Jr, Miller, D., Fitz, N. \& Sanders, M. (1971). Poult. Sci. 5o, 134.

Soeder, C. J. \& Pabst, W. (1970). Ber. dt. bot. Ges. 83, 607.

Varnish, S. A. \& Carpenter, K. J. (1971). Proc. Nutr. Soc. 30, 7oA.

Wang, S.-H., Crosby, L. O. \& Nesheim, M. C. (1973). Y. Nutr. 103, 384.

Woodham, A. A. \& Deans, P. S. (r97I). Proc. Nutr. Soc. 30, 59A.

Zebrowska, T. (1973). Proc. int. Amino Acid Symp., Brno A 34.

Zucker, H., Erbersdobler, H. \& Gropp, J. (1968). Z. Tierphysiol. Tierernähr. Futtermittelk. $23,193$. 